\title{
Hinweise Fur Autoren - Instructions To Authors
}

Ethische und rechtliche Voraussetzungen: Zur Publikation eingereichte Manu-skripte müssen bei Untersuchungen an Probanden oder Patienten die Erklärung cnthalten, daß das

Versuchsprotokoll von einer Ethikkommíssion genehmigt wur-de und somit den ethischen Standards der Deklaration von Helsinki 1964 und ihren Ergänzungen entspricht. Gleichzeitig ist die Einwilligung der Versuchs-person nach Aufklärung im Text des Manuskriptes zu fixieren. Hinweise, die auf die Identität der Versuchsperson schließen lassen, sind zu vermeiden. Tierversuchsvorhaben bedürfen gleichfalls der Genehmigung und müssen den Forderungen des deutschen Tierschutzgesetzes in seiner jeweils gültigen Fassung entsprechen. Auf diese Genehmigung ist im Manuskript hinzuweisen. Arbeiten, die nicht aus der Bundesrepublik Deutschland stammen, müssen einen vergleich-baren Hinweis tragen.

1. Allgemeines, Verlagsrecht Bitte senden Sie Ihr Manuskript direkt an die Schriftlcitung von INFUSIONS-THERAPIE UND TRANSFUSIONSMEDIZIN, z. Hd. Frau K. Gaida, Klinikum Großhadern, Institut für Anästhesiologie, Marchioninistraße 15, D-81377 München, Fax (089) 7409054.

Beiträge erscheinen als Übersichtsarbeiten, Originalarbeiten, laufende klini-sche Studien, Qualitätsmanagement, Kurzmitteilungen, Kasuistiken, klinisch-pathologische Konferenzen, Kongreßberichte, Informationen für die Klinik und Briefe an die Herausgeber.

Originalarbeiten, laufende klinische Studien und Kurzmitteilungen sollten in englischer Sprache abgefaßt werden. Alle anderen Beiträge können wahlweise in deutscher oder englischer Sprache eíngereicht werden.

Das Manuskript soil in satzreifem Zustand in vierfacher Ausfertigung einge-reicht werden. Die Entscheidung über die Annahme erfolgt aufgrund mehrerer Gutachten. Eine Kopie des Manuskripts soil grundsätzlich beim Autor verblei-ben. Typographische Gestaltung und redaktionelle Bearbeitung sind dem Ver-lag vorbehalten.

Für jedes Manuskript muß in eínem Begleitschreiben von alien Autoren durch Unterschrift bestätigt werden, daß die eingereichte Arbeit oder Teile hiervon (Ausnahme:

Kongreßmitteilungen) bislang weder veröffentlicht wurde(n) noch gegenwärtig zur anderweitigen Veröffentlichung eingereicht ist/sind, sowie daß alle Autoren das Manuskript gelesen haben und mit der Veröffentlichung in der vorliegenden Form einverstanden sind. Es ist Sache des Autors, die Nach-druckerlaubnis für Abbildungen, Tabellen usw. aus anderen Publikationen zu beschaffen. Mit der Annahme des Manuskriptes zur Publikation gehen alle Rechte auf den Verlag über. Ohne schriftliche Genehmigung des Verlages dür-fen diese Publikationen oder Teile daraus nicht in andere Sprachen übersetzt oder in irgendeiner Form mit mechanischen oder elektronischen Miíieln (einschließlich Fotokopie, Tonaufnahme und Mikrokopie) reproduziert oder auf einem Datenträger oder einem Computersystem gespeichert werden. Geschützte Markennamen müssen mit einem hochgestellten ${ }^{\circledR}$ bezeichnet werden. Die Verantwortung für die korrekte Befolgung dieser Vorschrift liegt aus-schließlich beim Autor.

2. Manuskripte 
Diese sollen in 1/2-zeiligem Abstand geschrieben sein, links und rechts einen angemessen breiten Rand aufweisen und (einschließlich Titelseite und Litera-turverzeichnis) kontinuierlich durchnumeriert sein. Folgende Gliederung wird empfohlen:

Titelseite mit Titel und Kurztitel der Arbeit in Deutsch und Englisch; Autoren-angabe; Institutsangabe in der Landessprache der Autoren.

Zusainmenfassung und Schlüsselwörter in Deutsch und Englisch. Zusammen-fassungen sollen 20 Schreibmaschinenzeilen nicht überschreiten und wie folet gegliedert sein (n. Haynes RB et al. Ann Intern Med 1990; 113:69-76): Für klinische Studien in Ziel, Design, Rahmen, Patienten (Teilnehmer), Interventionen, Ergebnisse, Schlußfolgerungen, Schlüsselwörter. Für experimentelle Untersuchungen in Hintergrund, Material und Methodik, Ergebnisse, Schlußfolgerungen, Schlüsselwörter. Für Übersichtsartikel in Ziel, Quellen, Auswahlkriterien, Ergebnisse, Schlußfolgerungen, Schlüsselwörter. In die Zusammenfassung gehören keine Literaturzitate, Tabellen, Abbildungen und Abbildungs- und Tabellenhinweise sowie allgemein gehaltene Aussagen. Zu einer Arbeit gehören 3-5 Schlüsselwörter.

Ethical and legal prerequisites: Manuscripts handed in for publication dealing with examinations of probands and patients must include the declaration that the trial protocol has been approved by an ethical committee and thus meets the standards of the Declaration of Helsinki (1964) and its amendments. At the same time the proband's informed consent has to be included in the manuscript. Information suitable to reveal the proband's identity is to be avoided.

Animal experiments demand consent as well and must meet the requirements of the German laws protecting animals in their current version. A reference to this approval must be included in the manuscript. Articles from outside the FRG must include a comparable notice.

1. General Remarks - Publishing Laws

Please send your manuscript directly to the editorial office of INFUSIONS-THERAPIE UND TRANSFUSIONSMEDIZIN, c/o Mrs. K. Gaida, Klinikum Großhadern, Institut für Anästhesiologie, Marchioninistraße 15, D-81377 Munich (FRG), Fax (089) 7409054.

Contributions are classified as review articles, original papers, ongoing clinical studies, quality management, short communications, casuistic contributions, clinical pathological conferences, congress reports, clinical information and letters to the editors.

Original papers, ongoing clinical studies and short communications should be written in English. All other contributions may be handed in optionally in German or English.

The manuscript should be submitted in four copies ready for printing. In a covering letter all authors of a manuscript must confirm by their signature that the submitted paper, or parts of it (with the exception of communications for congresses), was not published previously nor that it is under simultaneous consideration for publication elsewhere. The authors are furthermore asked to confirm that all of them have read the manuscript and that they agree to have it published in its present form. Acceptance of a manuscript is based on the evaluation by several referees. Each author should always keep a copy of the manuscript. The publisher reserves the right to edit the manuscript and decide on the layout.

It is the author's responsibility to obtain permission to reproduce illustrations, tables etc. from other publishers. Once the manuscript is accepted for publication, all the rights will be retained by the publisher. The publication, or parts of it, may not be translated into other languages, or reproduced by any mechanical or electronic means (including photocopying, recording and microcopying), or stored in a retrieval system without the publisher's written permission.

Registered trade names must be marked with the superscript registration symbol ${ }^{\circledR}$. It is the sole responsibility of the author to ensure that this rule is followed properly. 


\section{Manuscripts}

The manuscripts should be typed in a spacing of 172 lines with adequately wide margins (left and right). They should be consecutively numbered (including front page and reference list). We recommend the following division:

Front page with title and short title in German and English; author's name, institute name in the native language of the authors.

Summary and Key Words in German and English. Summaries should not exceed 20 typewritten lines and be arranged in the following manner (according to Haynes RB et al. Ann Intern Med 1990; 113:69-76): Clinical studies in Objective, Design, Setting, Patients (Participants), Interventions, Results, Conclusions, Key Words. Experimental investigations in Background, Materials and Methods, Results, Conclusions, Key Words. Review articles in Objective, Data Sources, Selection Criteria, Results, Conclusions, Key Words. Summaries should not include any references, tables, figures, references to figures and tables and general statements. Each article should have 3-5 key words.

Text pages should be divided into Introduction, Materials and Methods (optionally Patients and Methods), Results, Discussion. Footnotes (with numbers) are placed at the bottom of each page of the text.

Please use abbreviations as economically as possible. Special abbreviations should be written in full when first mentioned followed by the abbreviation in parentheses, e.g. adenosine monophosphate (AMP).

(C) 1995 S. Karger GmbH, Freiburg 